\title{
ISLAM PROGRESIF DAN DINAMIKA EKONOMI DALAM ISLAM
}

\author{
Nurana Haris \\ (STAI Payakumbuh. Email: nuranahariss@gmail.com)
}

\begin{abstract}
Islam Progresif merupakan kelanjutan dari gerakan Islam Liberal, di sisi lain juga muncul sebagai bentuk ungkapan ketidakpuasan terhadap gerakan Islam Liberal yang lebih menekankan pada kitik-kritik internal terhadap pandangan dan prilaku umat Islam yang tidak atau kurang sesuai dengan nilai-nilai humanis. pembahasan ini dimaksudkan untuk menganalisa bagaimana pandangan kelompok Islam Progresifterhadap ekonomi untuk kemudian dikaitkan dengan konsep dan praktek ekonomi Islam yang saat ini tengah berkembang. Mengingat konsentrasi utama Islam Progresif adalah topik-topik sekitar sekularisme, liberalisme, pluralisme, keadilan sosial dan jender, dan tema terkait, maka kajian ekonomi yang ada memang terbatas. Untuk itu, kajian ini akan difokuskan pada sumber yang terbatas tersebut. Selanjutnya akan juga dibahas dinamika perkembangan ekonomi Islam baik sebagai kajian kebijakan selama pemerintahan Islam maupun kajian akademik di masa kemunduran untuk menjawab dan mendialogkan sejumlah kritik yang disampaikan Islam progresif terhadap ekonomi Islam.
\end{abstract}

Kata Kunci: Progresif, Dinamika, Ekonomi

\section{PENDAHULUAN}

Islam Progresif atau progressive Islam merupakan istilah yang relatif baru dibandingkan dengan terma-terma lain, seperti "Islam Inklusif", "Islam Transformatif" dan "Islam Liberal”. Istilah Islam progresif ini pun yang dalam kajian Islam kontemporer digunakan oleh para akademisi dan aktivis sejak beberapa tahun terakhir secara substantif tidak jauh berbeda dengan terma lainnya. Istilah ini biasanya dinisbahkan kepada pemahaman-pemahaman dan aksi-aksi umat Islam yang memperjuangkan penegakan nilainilai humanis, seperti pengembangan civilsociety, demokrasi, keadilan, kesetaraan jender, pembelaan terhadap kaum tertindas dan pluralisme.

Pandangan kelompok Islam Progresif muncul sebagai kelanjutan dari gerakan Islam Liberal yang muncul sejak kurang lebih seratus lima puluh tahun yang lalu sekaligus ungkapan ketidakpuasan terhadap gerakan Islam Liberal sendiri yang lebih menekankan kritik internal terhadap Islam yang tidak atau kurang sesuai dengan nilainilai humanis dan melupakan kiritik terhadap modernitas, kolonialisme dan imprialisme.

Perhatian utama Islam progresif antara lain adalah topik-topik sekitar keterikatan dengan tradisi (engaging tradition), keadilan sosial (social justice), keadilan jender (gender justice), dan pluralisme. Mengingat Islam progresif merupakan 'kelanjutan' dari Islam Liberal, Islam Transformatif, dan sebagainya, maka pemikirpemikir yang dimasukkan dalam kelompok muslim progresif pun tersebar di berbagai negara. Diantara mereka adalah Abdul Karim Soroush dan Shirin Ebadi (Iran), Muhammad Shahrur dan Muhammad Habash (Suriah), Muhammad al-Talibi (Tunisia/Perancis), dan Fathullah Gülen (Turki/USA), (Sahiron Syamsuddin, 2007).

Selain itu sejumlah tokoh seperti Kecia Ali, Khaled Abou El Fadl, Farid Esack, Michael 
Green, Marcia Hermansen, Amir Hussain, Ahmet T. Karamustafa, Tazim R. Kassam, Scott Kugle, Ebrahim Moosa, Ahmad S. Moussalli, Farish Ahmad-Noor, Omid Safi, Sa'diyya Shaikh, Gwendolyn Zoharah Simmons, dan Amina Wadud dapat juga dimasukkan dalam kelompok ini. Dalam konteks Indonesia, sejumlah tokoh seperti Abdurrahman Wahid (Gus Dur) dan Nurcholish Madjid (Cak Nur) sering juga dimasukkan dalam tokoh pemikir Islam progresif. Demikian juga lembaga swadaya masyarakat maupun think thank lainnya yang dianggap berkomitmen untuk mengembangkan sekulerisme, liberalisme, dan pluralisme.

Sementara itu, pada sisi lainnya ekonomi Islam juga mengalami perkembangan yang pesat baik dalam skala global maupun lokal, Indonesia. Perkembangan ekonomi Islam dimaksud biasanya merujuk pada kajian keuangan dan bisnis yang biasa direpresentasikan dalam lembaga keuangan syariah, inovasi produk syariah, dan sebagainya. Demi melihat perkembangan pesat dalam keuangan dan bisnis tersebut, memang kerap muncul kegelisahan akademik di bidang ilmu ekonomi Islam (Islamic economics) berupa masih terbatasnya diskursus di bidang filsafat ekonomi Islam (Islamic economic philosophy). Kajian ilmu ekonomi Islam yang termanifestasikan dalam bidang praktis seperti perbankan dan keuangan Islam sebagai institusi yang berada dalam naungan ekonomi Islam telah terjadi sedemikian masif,

Sangat mudah menemukan kajian (dan bahkan kebijakan) ekonomi Islam dalam kaitannya dengan perbankan, asuransi, pasar uang, pasar saham, dan sebagainya dibandingkan menemukan kajian filosofis yang secara mendalam mengkaji fondasi dari ilmu ekonomi Islam itu sendiri. Dominannya kajian praktis di bidang perbankan dan keuangan Islam yang mengungguli kajian pada fondasi keilmuan ini menyisakan masalah mengingat seolah lembaga keuangan telah berevolusi dengan pesat padahal debat metodologi masih berlangsung.

Gambaran mengenai pentingnya membahas masalah metodologi dan pernakpernik filosofis lainnya dalam ilmu ekonomi Islam ini antara lain dapat ditemukan dalam kajian Seyyed Vali Reza Nasr, (Seyyed Vali Reza Nasr, 1987). Setelah menganalisa perkembangan ilmu ekonomi Islam pada 1980-an, ia sampai pada kesimpulan bahwa terdapat setidaknya tiga tahapan perkembangan ilmu ekonomi Islam, yaitu pertama ilmu ekonomi Islam dipresentasikan sebagai ide sosio-politik yang terutama dimaksudkan untuk membedakan dirinya dengan kapitalisme dan sosialisme; kedua ilmu ekonomi Islam dipertajam pada aspek praktis dari proses Islamisasi terutama pada perbankan dan keuangan; dan ketiga ilmu ekonomi Islam dipresentasikan sebagai sebuah pendekatan filosofis baru ilmu ekonomi.

Kebanyakan penulis dan pimpinan politik di negara muslim lebih banyak berkonsentrasi pada dua kelompok pertama, yaitu yang menekankan pembedaan ilmu ekonomi Islam dari kapitalisme dan sosialisme dan pengembangan praktisnya. Sementara konsentrasi pada bagian yang kedua masih sangat terbatas sehingga sangat mungkin menyebabkan (atau setidaknya menjadi salah satu sebab) masih terbatasnya pengembangan ilmu ekonomi Islam terutama body of knowledge dan metode di dalamnya.

Kurangnya perhatian dalam masalah filosofis ini membawa dampak lain yang perlu mendapat 
perhatian, yaitu pertama adanya kebingungan dalam menentukan apa yang menjadi isi bahasan atau objek kajian ilmu ekonomi Islam itu sendiri. Sebagian penulis, terutama yang berbasis ilmu ekonomi modern, menganggap ilmu ekonomi Islam cukup direpresentasikan oleh kajian di bidang perbankan dan keuangan, sedangkan penulis lainnya, terutama yang berbasis ilmuilmu syariah, melihat ilmu ekonomi Islam merupakan pengejawantahan ilmu figh atau lebih sempit lagi fiqh mu'amalah maliyah. Kondisi ini mengakibatkan munculnya masalah berupa signifikansi dan masa depan ilmu ekonomi Islam menjadi amat kabur dan kerangka keilmuannya menjadi terbatas.

Kedua perhatian yang begitu besar pada pengembangan lembaga keuangan Islam (terutama bank) dan kurangnya perhatian pada filsafat ilmu ekonomi Islam mengancam kemampuan Islam dalam untuk memunculkan sebuah madzhab pemikiran ekonomi. Ketiga dalam kondisi tidak ada filsafat ilmu ekonomi Islam yang memadai, para ekonom muslim tanpa sadar menggunakan kriteria dan standar Barat dalam membangun atau mengevaluasi kinerja ekonomi maupun menilai institusi bebas-riba.

Bahkan dalam konteks yang lebih jauh, ekonom muslim terjebak pada pandangan bahwa ilmu ekonomi Islam lebih merupakan proses menciptakan lembaga dan instrumen keuangan bebas-riba dan bukan merupakan sebuah pandangan hidup yang mengatur hubungan manusia dan lingkungannya, (Seyyed Vali Reza Nasr, 1987).

Mengacu pada kondisi di atas, maka tulisan singkat ini dimaksudkan untuk menganalisa bagaimana pandangan ekonomi dari kelompok Islam Progresif untuk kemudian dikaitkan dengan konsep dan praktek ekonomi Islam yang saat ini tengah berkembang. Mengingat konsentrasi utama Islam Progresif adalah topik-topik sekitar sekularisme, liberalisme, pluralisme, keadilan sosial dan jender, dan tema terkait, maka kajian ekonomi yang ada memang terbatas. Untuk itu, kajian ini akan difokuskan pada sumber yang terbatas tersebut. Selanjutnya akan juga dibahas dinamika perkembangan ekonomi Islam baik sebagai kajian kebijakan selama pemerintahan Islam maupun kajian akademik di masa kemunduran untuk menjawab dan mendialogkan sejumlah kritik yang disampaikan Islam progresif terhadap ekonomi Islam. Terakhir, pembahasan dan diskusi akan disampaikan dalam kaitannya dengan pengembangan ekonomi Islam dan Islam, sebelum sampai pada kesimpulan penutup.

\section{METODOLOGI PENELITIAN}

Untuk melakukan pembahasan atau penelitian ini maka dalam hal ini penulis memakai metode penelitian kepustakaan (library research), yaitu serangkaian kegiatan yang berkenaan dengan metode pengumpulan data pustaka, membaca dan mencatat serta mengolah bahan penelitian sumber primer dan sekunder yang mendukung tujuan penelitian, berupa menggunakan bahan tertulis, seperti buku, jurnal, majalah, dan sebagainya.

Berdasarkan teknik analisis data, penelitian ini merpakan penelitian kualitatif. Intrepretasi dan penyajian data dilakukan melalui metode deskriptif-analitis, yaitu penyusunan data melalui teks naratif, lalu dilakukan analisis data dan bangunan teori-teori yang siap diuji kebenaranya. 
Pandangan Islam Progresif Terhadap Ekonomi Islam

Pandangan tokoh Islam terhadap ekonomi Islam yang dikaji dalam tulisan ini mengacu pada pandangan Shalahuddin Jursyi. Kajian yang diacu terutama berhubungan dengan pandangan faksi Islam Progresif sempalan Gerakan Islamic Oriented yang ada dan berkembang di Tunisia. Tesis utama yang diajukannya adalah bahwa Islam tidak memiliki "sistem ekonomi yang siap terap". Hal ini mengacu pada fakta bahwa umat Islam selama ini telah dan masih memiliki beragam pandangan terkait sejumlah aspek seperti pembatasan hak milik dan kepemilikan, hubungan antara modal dan kerja, kewenangan pemerintah dalam membelanjakan harta negara, dan bahkan masalah hukum riba, (Shalahuddin Jursyi, 2004: 167).

Namun demikian, Islam Progresif, menurut Shalahuddin Jursyi tidak menafikan bahwa Alquran dan Hadits menyimpan nilai-nilai universal yang dapat difungsikan sebagai sebuah "ekonomi baru". Untuk sampai pada tahapan ini, ia menyaratkan bahwa nilai-nilai tersebut harus dikaitkan dengan "tujuan syariat" dan "karakteristik hubungan sosial yang berlaku pada saat ini" selanjutnya ditopang dengan alat analisis ilmiah yang digunakan ilmu ekonomi modern.

Tanpa pendekatan ini, petunjuk dalam nilainilai universal tersebut akan menjadi sekumpulan pandangan mundur mengingat bentuk lahirnya sangat dipengaruhi oleh fakta sejarah di masa lalu yang menurutnya relatif terbelakang jika dibandingkan kondisi saat ini.

Lebih jauh, Shalahuddin Jursyi juga melihat bahwa dengan segala kompleksitasnya saat ini, para ahli hukum Islam akan kesulitan memahami persoalan-persoalan ekonomi. Alasannya adalah bahwa pertama fiqh ekonomi yang ada relatif statis mengingat acuannya adalah kehidupan ekonomi di masa lalu; kedua perubahan dalam kehidupan ekonomi yang melahirkan ilmu ekonomi sebagai disiplin tersendiri dengan seluruh kompleksitas kajiannya, tidak mungkin diimbangi oleh kajian (fiqh yang mengacu pada) ekonomi klasik; ketiga ketidaktahuan para mufti terhadap perundang-undangan dan seluk-beluk ilmu ekonomi modern dan keempat ketidakberanian para mufti melakukan ijtihad dan pembaruan sehingga masih mengacu pada pandangan ulama klasik dengan kasus yang terjadi di masa lalu.

Dalam melakukan teoritisi ekonominya, Islam Progresif meyakini bahwa tidak layak teoritisasi dilakukan dari nol untuk kemudian dipaksakan pada realitas saat ini. Bentuk teoritisasi yang diacu adalah berdasarkan realitas kekinian, interaksi dialektis didalamnya, sekaligus tetap mengaitkannya dengan keyakinan teologis yang dibawa. Jika dikaitkan dengan pandangan Marxisme tentang 'pertentangan kelas' sebagai "istilah kunci yang mampu menafsirkan semua fenomena sejarah dan peradaban", Islam Progresif tidak sepenuhnya menerima generalisasi semacam ini, meskipun tetap menerimanya sebagai alat analisis untuk masyarakat dunia ketiga sekaligus menganggapnya tidak bertentangan dengan konsep Islami yang menjelaskan latar belakang sejarah pergulatan para nabi dan kelompok borjuis di masa mereka, (Shalahuddin Jursyi, 2004).

Terkait isu keadilan dalam pertumbuhan ekonomi, Islam Progresif menolak pertumbuhan yang mengorbankan manusia dan memposisikannya tidak lebih sebagai barang, 
menolak pertumbuhan yang menguntungkan segelintir orang untuk menguasai kekayaan nasional, dan juga menolak pertumbuhan yang semata-mata menjadikan konsumerisme, persaingan, laba, dan kesejahteraan sebagai tolak ukur mengalahkan nilai-nilai keadilan dan persaudaraan. Meskipun mengakui pentingnya keadilan sebagai idealisme, namun Islam Progresif juga mengakui bahwa masyarakat tidak berkelas, yang diikuti debirokratisasi dan kepemilikan bersama merupakan sesuatu yang sulit diwujudkan dan diterima dalam realitas kekinian.

Islam Progresif cenderung lebih mengadopsi model pendekatan bertahap dalam mewujudkan keadilan, melalui program perjuangannya seperti "kebebasan aktivitas berserikat, land reform, memprioritaskan peningkatan kualitas hidup para petani agar bisa mencapai swasembada pangan, dan keniscayaan persatuan bangsa Arab untuk mengembangkan industri-industri berat.

\section{Dinamika Ekonomi Islam}

Sebagian besar pengkaji ilmu ekonomi Islam baik di Barat maupun di Timur mengakui bahwa ilmu ekonomi Islam memiliki akar hingga masa awal munculnya Islam di Jazirah Arab dan terus berkembang hingga masa puncak peradaban Islam. Pada masa awal Islam, yaitu masa dimana Nabi Muhammad Saw menerima wahyu, Alquran maupun As-Sunah menjadi fondasi bagi pemikiran ekonomi. Masa ini berlangsung antara 610-632 H, (Ahmed El-Ashker dan Rodney Wilson (2006: 91).

Dalam konteks ini, perlu disadari bahwa Alquran dan As-Sunah pada dasarnya memang tidak memberikan sebuah sistem ekonomi yang komprehensif bersifat ilahiah yang mampu menjawab setiap persoalan ekonomi mendetail baik pada masa tersebut, masa sekarang maupun masa mendatang. Kedua sumber hukum Islam tersebut, Alquran dan As-Sunah, lebih banyak kerangka dasar (foundational framework) yang kuat yang darinya, sebuah sistem ekonomi sedetail mungkin dapat disusun.

Selanjutnya pada masa kepemimpinan Khulafaur Rasyidah, para sahabat dibawah pimpinan Abù Bakr R.A. (632-634), 'Umar R.A. (634-644), Utsmàn R.A. (644-656), dan 'Alî K.W. (656-661) menjalankan aktivitas ekonomi dengan berpedoman pada Alquran dan As-Sunah dilengkapi dengan pemahaman serta ijtihad yang cemerlang dari para sahabat pilihan tersebut. Umat Islam terus berkembang pada masa Dinasti Umayyah yang mengalami tidak hanya perluasan wilayah tetapi juga pola kehidupan dari yang semula berlatar kehidupan padang pasir menjadi masyarakat perkotaan seiring dengan makin banyaknya wilayah taklukan. Tidak hanya itu, perubahan komponen masyarakat juga mewarnai masyarakat muslim kala itu karena banyaknya masyarakat non-Arab yang masuk dan berperan dalam Islam. Perubahan semacam ini meniscayakan kebijakan-kebijakan ekonomi yang juga inovatif di zamannya.

Sejumlah pemikiran pun muncul dari para ahli terutama pada masa setelah Dinasti Umayyah, yaitu Dinasti Abbasiyah. Dalam rentang panjang tarikh yang dilewati umat Islam pada puncak kejayaan dinasti ini, yang juga sering dianggap sebagai puncak kejayaan Islam, sejumlah nama besar pun muncul dengan berbagai karya keilmuan bidang ekonomi yang jauh melihat ke depan melewati masanya. Sejumlah pemikir tersebut diantaranya adalah Abù Yùsuf (113-182 
H, 731-798 M) dengan karyanya Kitàb al-Kharàj, Al-Syaibànì (132-189 H, 750-804 M) dengan karyanya Kitàb al-Iktisàb, Abù-Ubaid (W. 224 H, $838 \mathrm{M}$ ) dengan karyanya Kitàb al-Amwàl, dan Abdullah al-Harits bin Asad al-Muhasibì, (W. 243 H, 857 M) dengan karyanya Kitàb Risalat al-Iktisàb wa al Wara', (Dadan Muttaqien, 2011).

Pada masa setelah Dinasti Abbasiyah mulai mereduppun, sejumlah pemikir besar dalam bidang ekonomi tetap muncul memberikan kontribusi bagi pengembangan kemajuan umat. Diantara mereka adalah Abù al-Hasan al-Màwardì (364-450 H/ 972-1058 M) dengan karyanya alAhkàm al-Sùltàniyyah, Al-Ràghib al-Ashfahànì (w. 502 H/1108 M) dengan karyanya al-Zari"ah f. Makàrim al-Syari"ah, Abù Hamid al-Ghazàlì (450-505 H/1058-1111 M) dengan karyanya Ihya' Ulìm al-Din, Ja'far al-Dìmasyqì (akhir abad ke-12 M) dengan karyanya al-Isyarah fi Mahàsin al-Tijarah, Ibn-al-Ukhùwwah (w. 1329 M) dengan karyanya Mảalim al-Qürbah fi Ahkàm al-Hisbah, Ibn Taymìnah (661-728 H/1263-1328 M) dengan karyanya al-Hisbah fi al-Islam, dan Ibn-Khaldùn (1332-1406) dengan karyanya alMùqaddimah (merupakan pendahuluan bagi kitab Al-'Ibar wa Diwan al-Mubtada' wa al-Khabar fi Ayam al-Arab wa al-Ajam wa al-Barbar wa Man 'Asharahum min Dzaw al-Shulthan al-Akbar), (Dadan Muttaqien, 2011).

Namun demikian, meskipun secara historis telah tumbuh sejak awal keberadaan Islam itu sendiri, ilmu ekonomi Islam belum dapat dianggap sebagai ilmu yang berdiri sendiri, terutama berkaitan dengan kelengkapan kerangka studinya yang spesifik dan maju. Sejumlah alasan dapat diajukan untuk menjelaskan masalah ini.
Pertama belum adanya kebutuhan yang mendesak akan sebuah kajian ekonomi yang independen dan dalam pada masa itu, terutama dikaitkan dengan masih relatif sederhananya permasalahan ekonomi yang muncul dalam kehidupan umat. Masalah-masalah ekonomi dirasa cukup pada waktu itu untuk dikaji dalam tinjauan ilmu-ilmu yang sudah mapan semisal fiqh, falsafah, maupun siyasah.

Alasan kedua adalah bahwa meskipun sejumlah ilmuwan muslim telah menyusun berbagai kajian ilmu ekonomi Islam dalam karyanya, belum ada dorongan yang kuat untuk mendiskusikan tema ekonomi secara khusus dan sistematis. Hal ini berimplikasi pada banyaknya kajian ilmu ekonomi Islam yang seolah bertebaran dan berserakan di berbagai kitab klasik dengan beragam pendekatan kajiannya, tanpa dikumpulkan menjadi satu disiplin yang matang. Alasan ketiga yaitu kemunduran peradaban Islam yang terutama dialami setelah kejatuhan Baghdad (1258 M), di wilayah kekuasaan Islam bagian Timur dan Granada (1492 M) diwilayah kekuasaan Islam bagian Barat, (M. Abdul Karim, 2007: 161).

Kemunduran peradaban Islam kemudian membawa masyarakat muslim dalam masa transisi dalam pemikiran ekonomi Islam. Masa transisi dalam hal ini utamanya dimaksudkan sebagai masa transisi menuju pemikiran ekonomi Islam kontemporer. Pada masa yang berlangsung selama abad 18-19 M ini, sejumlah penulis telah ikut berkontribusi dalam pengembangan ilmu ekonomi Islam, mulai dari Muhammad bin Abdul Wahhab (1703-1792 M), Syah Waliyullah Dihlawi (17461824 M), Jamaluddin Al-Afghani (1838-10897), Muhammad Abduh (1849-1905). Karakteristik 
kajian pada masa ini umumnya adalah pertama eksplorasi ulang terhadap sumber-sumber ajaran Islam yang utama, yaitu Alquran dan As-Sunah; kedua mengevaluasi kembali model intelektual Islam yang umum dan hubungannya dengan kondisi kehidupan umat Islam; dan ketiga mendefinisikan dan mengidentifikasi tantangan eksternal terutama Barat dan mencari pemecahannya dari perspektif intelektual Islam untuk menjadi sebuah sintesa pemecahan masalah dengan perspektif Barat dan Islam, (Hafas Furqani dan Zakariya Man, 2008).

Perkembangan ilmu ekonomi Islam kontemporer kemudian tergambar pada banyaknya kontribusi fuqaha atau penulis dengan latar belakang ilmu-ilmu Islam mulai dari Abul A’la Al-Maududi, Sayyid Qutb, Muhammad Baqir Al-Sadr dan lain sebagainya pada masa sebelum tahun 1970-an. Karya mereka yang tersebar dalam berbagai buku maupun terbitan berkala utamanya merupakan kajian ekonomi yang sifatnya masih umum, mengagungkan Islam di atas sistem lainnya, berorientasi fiqh, kurang menggunakan kerangka ekonomi, dan menyerang pandangan Barat, baik kapitalisme maupun sosialisme. Masa setelah tahun 1970-an terutama setelah Konferensi Ilmu Ekonomi Islam pertama kali digelar di Mekkah pada 1976 menjadi tonggak bagi era baru dimana ilmu ini didekati dengan pendekatan ekonomi standar, menggunakan alat analisa matematika, ekonometrika, dan lainnya untuk mencari jawaban pada level mikro ataupun makro.

\section{Perbandingan Ekonomi Islam dan Pandangan Islam Progresif}

Kritik utama Islam progresif yang perlu disikapi adalah terkait ketiadaan sistem ekonomi Islam siap terap karena keyakinan bahwa dinamika hukum Islam terus menerus menunjukkan perkembangan yang tidak selalu menampilkan tafsiran tunggal. Terhadap pandangan ini, harus diakui bahwa jika yang dimaksud sistem ekonomi siap terap itu bersifat final, detail, dan siap digunakan di mana saja dan kapan saja, Islam memang tidak secara spesifik menyebut hal tersebut. Islam di masa awal, sebagaimana dijelaskan sebelumnya, memberikan bekal berupa Alquran dan As-Sunnah yang dari keduanya sejumlah pemikiran ekonomi dapat diturunkan.

Secara historis, bukti kemajuan peradaban Islam yang begitu kuat dalam mengembangkan ilmu pengetahuan dan teknologi sebenarnya secara tidak langsung dapat dijadikan bukti bahwa berbagai ijtihad kolektif umat Islam di bidang ekonomi telah terjadi dan berhasil. Bangsa-bangsa yang maju peradabannya dengan bertopang pada ilmu pengetahuan dan teknologi tentulah memiliki fondasi ekonomi yang kuat.

Kritik selanjutnya terutama dikaitkan dengan kompetensi para yuris muslim dalam pengembangan ekonomi Islam. Jika tugas menganalisa ekonomi dibebankan semata kepada para yuris, memang akan sangat sulit, meskipun mungkin, untuk mengkaji ekonomi Islam secara paripurna, mengingat kompleksitas kajian dalam ilmu ekonomi (economics) dan hukum Islam (fiqh). Namun demikian, sebagaimana telah disinggung sebelumnya, sejumlah perkembangan akademik yang terjadi secara tegas menunjukkan bahwa ekonomi Islam pada saat ini sudah tidak menjadi monopoli yuris muslim. Kajian ekonomi Islam telah menjadi kajian multidimensi dengan beragam latar belakang keahlian, baik ekonomi maupun hukum Islam, yang kemudian 
disintesakan dalam pandangan (teori) maupun aplikasi (kebijakan) ekonomi sesuai level kebutuhan dan kapasitas suatu perekonomian ataupun lembaga keuangan.

Catatan dari Islam progresif tentang perlunya kajian ekonomi Islam menggabungkan tujuan syariah dan alat analisis modern dalam ilmu ekonomi, sebenarnya juga telah dilakukan dan bahkan pada tahap tertentu telah dimodifikasi sesuai dengan perubahan yang terjadi. Mengandalkan ilmu ekonomi modern semata, saat ini akan sangat berbahaya tidak hanya bagi otensitas kajian ekonomi Islam, tetapi juga bagi keberlangsungan ilmu itu sendiri dan manusia yang mempelajarinya. Hal ini mengingat saat ini ilmu ekonomi modern sedang berada dalam titik rendah karena sejumlah kegagalannya dalam memberikan solusi atas masalah ekonomi dunia. Bahkan secara ekstrim banyak pandangan yang menjustifikasi ilmu ekonomi modern sebagai sebab utama krisis ekonomi, keuangan, dan utang yang selama ini dan masih terus terjadi.
Dengan demikian akan naif sekali jika ekonomi dalam konteks pemahaman umat Islam harus dipaksa mengikuti 'kecanggihan' alat analisis ilmu ekonomi modern yang sedang mengalami masalah serius. Catatan selanjutnya dari Islam progresif terkait idealisme keadilan dalam banyak hal sebenarnya juga berdekatan dengan tujuan-tujuan yang ingin dicapai oleh ekonomi Islam. Ilmu ekonomi Islam didasari pada kesadaran bahwa dalam kehidupan orientasi akhir yang menjadi tujuan adalah mencapai falah. Falah bagi seorang muslim sebagai tujuan hidup sebagai motivasi utama, tidak hanya menyangkut pencapaian di dunia tetapi juga di akherat. Falah adalah kemenangan dan kemuliaan hidup yang mencakup aspek yang lengkap dan menyeluruh bagi kehidupan manusia. Muhammad Akram Khan menjelaskan beberapa komponen dalam falah yang mencakup aspek mikro dan makro sebagaiman disajikan dalam tabel berikut, (Muhammad Akram Khan, 1994: 35):

Tabel 1 Aspek Mikro dan Makro dari Falah

\begin{tabular}{|c|c|c|c|}
\hline NO & Unsur Falah & Aspek Mikro & Aspek Makro \\
\hline \multirow[t]{4}{*}{1.} & \multirow[t]{4}{*}{ Kelangsungan hidup } & Kelangsungan hidup biologis & Keseimbangan ekologi dan lingkungan \\
\hline & & Kelangsungan hidup ekonomi & Penyediaan sumber daya alam \\
\hline & & Kelangsungan hidup sosial & Kebersamaan sosial, ketiadaan konflik sosial \\
\hline & & Kelangsungan hidup politik & Jati diri dan kemandirian \\
\hline \multirow[t]{2}{*}{2.} & \multirow[t]{2}{*}{ Kebebasan Berkeinginan } & Terbebas kemiskinan & Penyediaan sumber daya untuk penduduk \\
\hline & & Kemandirian hidup & $\begin{array}{l}\text { Penyediaan sumber daya untuk generasi } \\
\text { mendatang }\end{array}$ \\
\hline \multirow[t]{2}{*}{3.} & \multirow[t]{2}{*}{ Kekuatan dan harga diri } & Harga diri & Kekuatan ekonomi dan kebebasan dari utang \\
\hline & & Kemerdekaan, perlindungan terhadap hidup dan kehormatan & Kekuatan militer \\
\hline
\end{tabular}

Dengan memahami prakonsepsi tentang falah seperi di atas, maka individu muslim sebagai pribadi dan anggota masyarakat akan mampu memposisikan dirinya secara tepat dalam proses ekonomi apapun itu untuk mencapai falah yang tidak hanya diarahkan bagi capaian pribadinya, tetapi juga masyarakat Islam pada umumnya. Selain tujuan mencapai falah, dalam skema etika 
Islam, seorang manusia pada dasarnya menegakkan tiga hubungan simultan, yaitu dengan Tuhan, dirinya sendiri, dan masyarakat. Aksioma etika Islam tersebut adalah, (Naqvi Syed Nawab Haider, 2003: 50). Pertama, kesatuan (tauhid) yang mengindikasikan kepercayaan penuh dan murni terhadap kesatuan Tuhan yang menunjukkan dimensi vertikal dalam Islam. Kedua, keseimbangan (al-'adl wa al-ihsan) yang menunjukkan kesejajaran sosial sebagai cita-cita Islam. Ketiga, kehendak bebas (ikhtiyar) yang menekankan potensi manusia untuk berkembang sesuai dengan pilihan-pilihan yang ada. Keempat, tanggung jawab (fardh) yang menjadi penyeimbang bagi kebesasan dalam Islam.

Aksioma etika ini tentu saja sesuai dengan pandangan utama Islam progresif yang memang menginginkan keadilan dalam kehidupan ekonomi dan sosial. Hanya yang membedakan kemudian, Islam progresif tidak serta merta menganggap penerapan nilai-nilai Islam dalam kajian fiqh secara otomatis dapat mencapai tujuan tersebut. Sedangkan dalam konteks ekonomi dan keuangan Islam, penerapan ajaran Islam dalam fiqh tersebut menjadi sesuatu yang inheren dan mutlak, karena tanpa tuntutan hukum tersebut, niscaya sulit mewujudkan falah dalam kehidupan.

\section{PENUTUP}

Paparan di atas menunjukkan bahwa, dari sumber terbatas, pandangan Islam progresif terhadap ekonomi Islam dapat dianggap bertentangan pada sejumlah isu dan bersesuaian pada isu lainnya. Ekonomi Islam dengan dinamikanya memang lebih mendekati Fiqh sebagai acuan, berbeda dengan Islam progresif yang menuntut Fiqh baru yang lebih humanis.

\section{DAFTAR PUSTAKA}

El-Ashker, Ahmed dan Wilson, Rodney. (2006). Islamic Economics: A Short History. Leiden: Koninklijke Brill NV.

Furqani, Hafas dan Man, Zakariya. (2008). The Emergence of Contemporary Islamic Economics: A Sketch of Its Historical Development. Makalah dipresentasikan dalam 1st International Workshop on Islamic Economics: Exploring Islamic Economic Theory. -12 Agustus.

Haneef, Mohammed Aslam. (2005). "Islamisai Ilmu Ekonomi: Apa yang Salah?” Islamia, Majalah Pemikiran dan Peradaban Islam, Thn. 1, No. 6.

Hoetoro, Arif. (2007), Ekonomi Islam: Pengantar Analisis Kesejarahan dan Metodologi. Malang: Badan Penerbit Fakultas Ekonomi Universitas Brawijaya.

Jursyi, Shalahuddin. (2004). Membumikan Islam Progresif(terj.). Jakarta: Paramadina.

Karim, M. Abdul. (2007). Sejarah Pemikiran dan Peradaban Islam. Cet. 1. Yogyakarta: Pustaka Book Publisher.

Khan, Muhammad Akram. (1994). An Introduction to Islamic Economics. Islamabad: Institute of Islamic Thought and Institute of Policy Studies.

Muttaqien, Dadan. (2011). Pengembangan SDM Ekonomi Islam. Makalah disampaikan dalam Seminar Nasional Ekonomi Islam. Yogyakarta, 11 Mei.

Naqvi, Syed Nawab Haider. (2003). Menggagas Ilmu Ekonomi Islam. Diterjemahkan dari 
Islam, Economics and Society. M. Saiful Anam dan Muhammad Ufuqul Mubin. Yogyakarta: Pustaka Pelajar.

Nasr, Seyyed Vali Reza. (1987). “Toward a Philosophy of Islamic Economics "dalam Muslim World.
Wartoyo. (2010). Bunga Bank Abdullah Saeed vs Yusuf Qaradhawi: Sebuah Dialektika Pemikiran, dalam Jurnal Ekonomi Islam La Riba, Vol. IV., No. 1 